\title{
MUSIUM SENI DIGITAL
}

\author{
Stefanie Evelyn ${ }^{1)}$, Sutrisnowati Machdijar ${ }^{2)}$ \\ 1)Program Studi S1 Arsitektur, Fakultas Teknik, Universitas Tarumanagara, stefanieevelyntep@gmail.com \\ 2)Program Studi S1 Arsitektur, Fakultas Teknik, Universitas Tarumanagara, sutrisnowatim@ft.untar.ac.id
}

\begin{abstract}
Abstrak
Kota BSD merupakan suatu kawasan yang direncanakan akan menjadi pionir Integrated Smart Digital City, dipicu oleh penduduk BSD yang didominasi oleh generasi milenial dan generasi alfa yang tumbuh dengan mengikuti perkembangan teknologi. Generasi milenial memiliki tingkat kecemasan, stress, dan depresi yang tinggi. Untuk mengurangi tingkat stress yang tinggi itu seni memiliki peran yang penting dimana seni dapat mengubah emosi dan perilaku seseorang, memberi dampak positif pada manajemen stress, mengurangi tingkat kecemasan dan meningkatkan mood. ${ }^{1}$ Teknologi digital telah memungkinkan seni untuk melampaui batasan-batasan yang ada, sehingga seni di masa sekarang dan di masa yang akan datang menjadi lebih dinamis, fleksibel sesuai dengan karakter generasi millennials. Oleh karena itu, perancangan ini bertujuan untuk menyediakan wadah interaksi antara seni dengan manusia dan antara sesama manusia dari berbagai golongan dengan memanfaatkan kemajuan teknologi untuk memaksimalkan interaksi yang terjadi serta menumbuhkan pemikiran kreatif dan ekspresi diri melalu seni digital. Perancangan dilakukan dengan metode survei dan shape grammar. Museum dimana pengunjung dapat mengeksplorasi seni digital dan berinteraksi langsung dengan karya seni tersebut serta mengekspresikan emosinya secara bebas menjadi museum yang dibutuhkan generasi milenial di masa ini.
\end{abstract}

Kata kunci: Milenial; seni digital; stress; teknologi

\begin{abstract}
BSD City is an area that is planned to be a pioneer of the Integrated Smart Digital City, triggered by the population of BSD which is dominated by millennials and alpha generations who grow up following technological developments. Millennials have a high level of anxiety, stress and depression. To reduce high levels of stress art has an important role where art can change one's emotions and behavior, have a positive impact on stress management, reduce anxiety levels and improve mood. Digital technology has allowed art to go beyond existing boundaries, so that art in the present and in the future will be more dynamic, flexible in accordance with the character of the millennials generation. Therefore, this design aims to provide a forum for interaction between art and humans and among fellow human beings from various groups by utilizing technological advances to maximize the interactions that occur and foster creative thinking and self-expression through digital art. The design is done by survey method and shape grammar. A museum where visitors can explore digital art and interact directly with the artwork and express their emotions freely into a museum, is needed by the Millennials at this time.
\end{abstract}

Keywords: Digital art; millennials; stress; technology

\section{PENDAhUluan}

Jakarta sebagai ibukota Indonesia merupakan salah satu kota di Indonesia yang berkembang pesat dengan kepadatan tinggi dan jumlah penduduknya yang terus meningkat setiap tahunnya. Untuk menyangga beban Jakarta yang semakin padat dan kurangnya lahan untuk bermukim, dikembangkan beberapa kawasan untuk menjadi kota baru dan pemukiman, salah satunya adalah BSD.

\footnotetext{
${ }^{1}$ Sabine C. Koch \& Fuchs T, Embodied Arts Therapies, (Arts Psychother, 2011)
} 
BSD City merupakan suatu kawasan yang berada di antara Kabupaten Tangerang dan Kota Tangerang Selatan, yang direncanakan akan menjadi pionir Integrated Smart Digital City, dipicu oleh penduduk BSD yang didominasi oleh generasi milenial dan generasi alfa yang tumbuh dengan mengikuti perkembangan teknologi (Digital Natives).

Penduduk BSD City didominasi oleh usia muda dan produktif. Pada usia produktif, terutama pada generasi milenial, tingkat kecemasan, stress dan depresi cukup tinggi, dimana tingkat bunuh diri pada generasi milenial meningkat 3 kali lipat dibandingkan generasi sebelumnya di umur yang sama. ${ }^{2} \mathrm{Hal}$ ini disebabkan karena generasi millennial tumbuh dalam lingkungan yang kompetitif, dengan tuntutan pendidikan serta pekerjaan yang tinggi.

Untuk mengurangi tingkat stress yang tinggi itu seni memiliki peran yang penting yaitu dengan menggunakan pendekatan yang kreatif dan non verbal yang sering disebut dengan Creative Art Therapies, ${ }^{3}$ dimana seni dapat mengubah emosi dan perilaku seseorang, memberi dampak positif pada manajemen stress, mengurangi tingkat kecemasan dan meningkatkan mood. ${ }^{4}$ Sedangkan menurut Susan Krauss Whitbourne Ph.D. (2010) rekreasi dan mengambil waktu istirahat dari rutinitas sehari-hari juga dapat mengurangi stress. ${ }^{5}$

\section{Generation stress}

Millennials report higher stress levels, use more outpatient mental health services

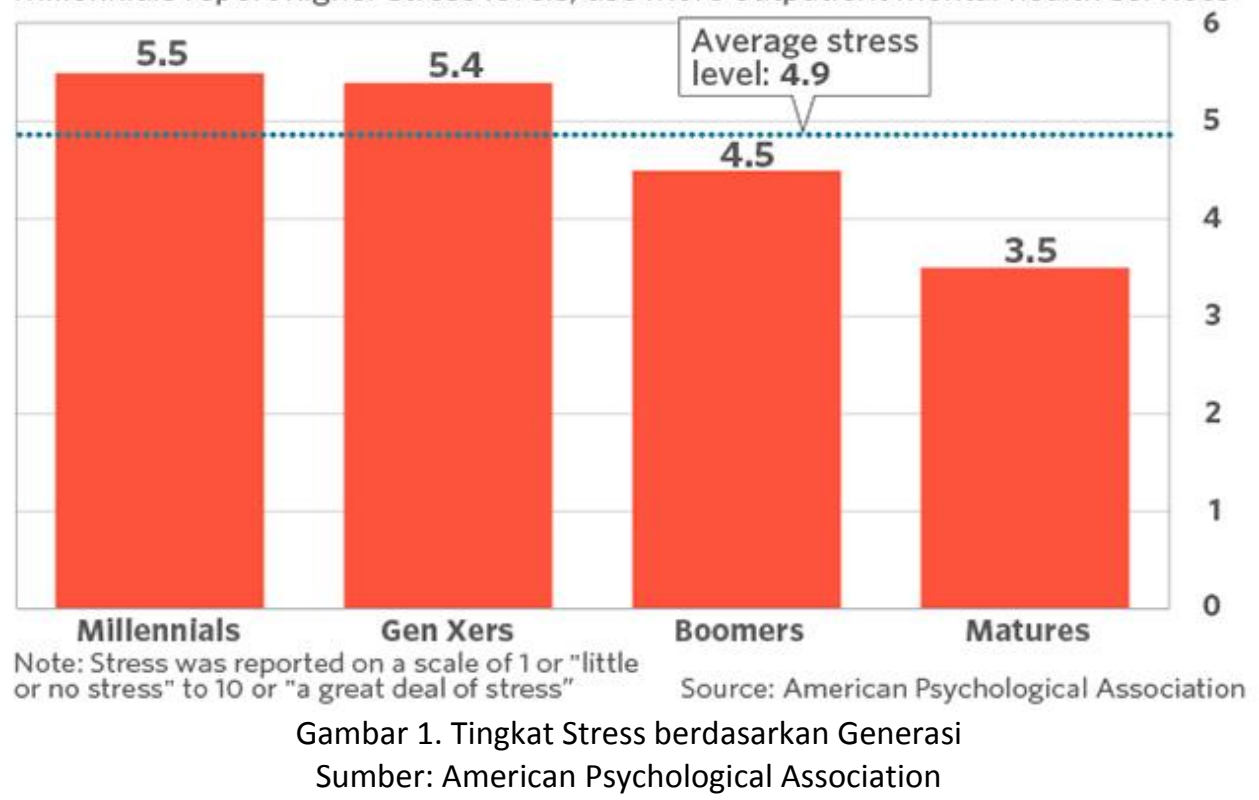

Teknologi digital telah memungkinkan seni untuk melampaui batasan-batasan yang ada dan muncul aliran seni digital. Selain karena perkembangan teknologi, munculnya seni digital juga dipengaruhi oleh karakteristik generasi Millennial.

Karakter generasi milenialyang kritis dan beredukasi cenderung mencari hal baru yang menarik dan atraktif. Oleh karena itu, museum dimana pengunjung dapat mengeksplorasi seni yang menarik, atraktif dan berinteraksi langsung dengan karya seni tersebut serta mengekspresikan emosinya secara bebas menjadi tipe museum yang dibutuhkan generasi Millenial di masa ini, baik sebagai pengunjung maupun kontibutor.

\section{Rumusan Permasalahan}

- Program seperti apa yang dapat mewadahi kebutuhan generasi milenial?

\footnotetext{
${ }^{2}$ American Psychological Association

${ }^{3}$ Sabine C. Koch \& Fuchs T, Op.Cit.

${ }^{4} \mathrm{Ibid}, \mathrm{hlm} .276-280$

${ }^{5}$ Joudrey, A.D. \& Wallace, J.E., Leisure as a Coping Resource: A Test of the Job Demand Control Support Model, (Human Relations, 2009), hlm. 62, 195-217
} 
- Bagaimana karakter dan perilaku generasi millennial membentuk arsitektur museum?

\section{Ruang Lingkup}

- Generasi milenial sebagai pelaku yang diamati karakter dan perilakunya dan sebagai pengguna utama dari proyek yang dikerjakan

- Pelayanan mencakup skala kota

- Jenis karya seni yang dipamerkan terfokus pada seni digital yang ditampilkan di layar, tembok, lantai atau media lainnya dan karya seni digital yang interaktif

\section{Visi Proyek}

- Menyediakan wadah interaksi antara seni dengan manusia dan antara sesama manusia dari berbagai golongan.

- Memperkaya kehidupan generasi sekarang maupun yang akan datang dengan menumbuhkan pemikiran kreatif dan ekspresi diri melalu seni digital.

\section{Misi Proyek}

- Berkontribusi dalam perkembangan seni digital.

- Mengaburkan batasan antara seni dan manusia dengan memanfaatkan perkembangan teknologi.

- Mengadakan event-event yang menarik dan mendidik untuk publik.

- Mempresentasikan seni digital yang mengandung unsur kehidupan yang mendidik dan menghibur.

Digital Art Museum ini dapat menjadi fungsi penting dalam konteks lingkungan dan dapat merubah pandangan masyarakat umum terhadap tipe museum. Museum secara fisik terintegrasi dengan kehidupan kota yang padat dan beradaptasi dengan perubahan yang akan muncul ke depannya. Museum menjadi ruang dimana penduduk bisa lepas dari beban pikiran keseharian dan hiruk pikuk kota.

\section{KAJIAN LITERATUR}

\section{Generasi Y (Millenials)}

Generasi y atau yang sering disebut generasi milenial menjadi isu yang menarik dan menyebar luas, sejak publikasi Howe \& Strauss pada tahun 2000 yang berjudul Millennials Rising. Generasi ini menjadi perhatian karena memiliki jumlah terbesar secara global, memiliki tingkat pendidikan yang tinggi, sedang dalam usia produktif, sangat mudah dipengaruhi tren dan sangat konsumtif. ${ }^{6}$ Sehingga, generasi milenial memiliki signifikansi yang besar dan dapat membawa perubahan yang besar terhadap dunia.

Generasi milenial merupakan generasi yang lahir antara tahun 1981-1994, dimana generasi ini tumbuh disaat perkembangan teknologi dan informasi digital muncul dan berjalan cepat, generasi ini disebut dengan istilah digital native. Karena itu generasi milenial lebih berpikiran terbuka dan lebih mudah beradaptasi terhadap perkembangan teknologi yang cepat dibandingkan generasi-generasi sebelumnya. ${ }^{7}$

Sejak tahun 1980-an, pemerintah dunia berfokus pada pengembangan diri, di bidang ekonomi dan sosial, sehingga sejak itu orang-orang terus meningkatkan kemampuan dirinya, terutama dalam bentuk edukasi, karir dan status sosial. Fenomena ini dialami oleh generasi $x$ yang saat itu sedang dalam usia produktif dan membuat generasi ini menuntut generasi $y$ untuk meningkatkan kemampuan dirinya sampai mencapai tingkatan yang bisa dibilang sempurna.

Tumbuh dalam lingkungan yang kompetitif, tuntutan pendidikan yang tinggi dan kebutuhan pekerjaan dengan gaji yang signifikan membuat tingkat perfeksionisme generasi ini meningkat berdasarkan riset yang dilakukan terhadap 164 mahasiswa dari tahun 1989 sampai 2016, dimana pengaruh faktor internal meningkat $10 \%$, faktor eksternal $33 \%$ dan faktor lainnya

\footnotetext{
${ }^{6}$ Berger, A.A, Cultural Perspectives on Millennials, (London: Palgrave Macmillan, 2018)
}

${ }^{7}$ lbid. 
meningkat $16 \%{ }^{8} \mathrm{Hal}$ ini merupakan salah satu faktor yang menyebabkan generasi millennial memiliki tingkat kecemasan, stress, dan depresi yang tinggi, dimana tingkat bunuh diri pada generasi milenial meningkat 3 kali lipat dibandingkan generasi sebelumnya di umur yang sama.
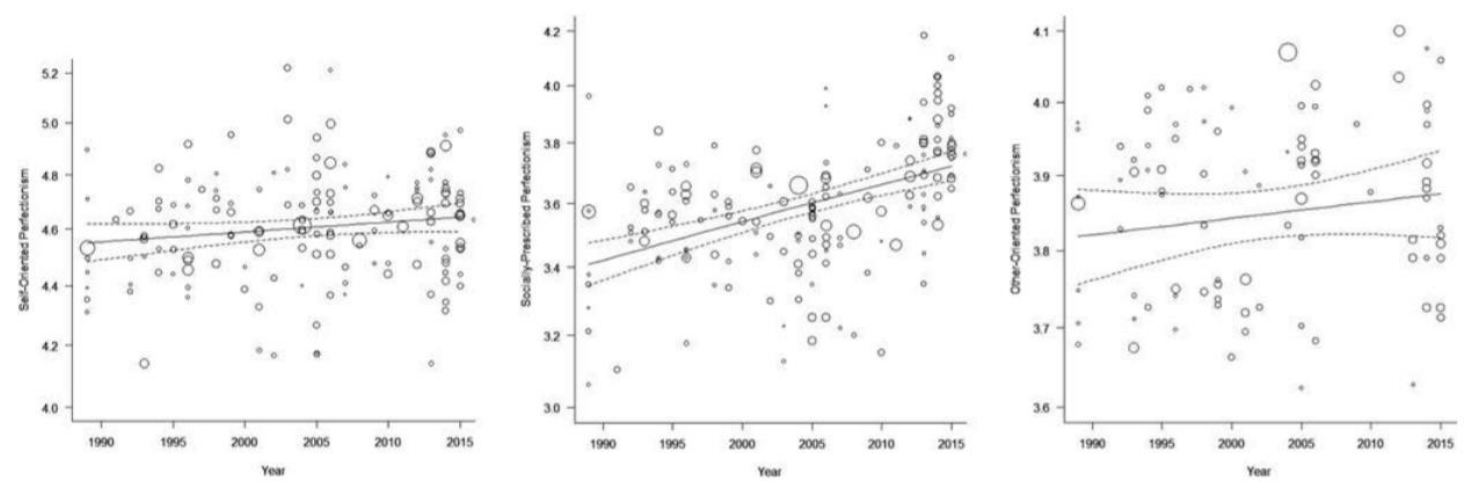

Gambar 2. Skala Perfeksionisme berdasarkan Faktor Internal, Eksternal, dan Lainnya Sumber: American Psychological Association

\section{Seni}

Pengertian mengenai seni terus berubah seiring dengan perubahan jaman. Di masa lalu, seni diartikan sebagai suatu representasi atau imitasi (Plato, 1955), sebagai perantara untuk mengekspresikan perasaan (Tolstoy, 1955) dan sebagai bentuk yang signifikan (Bell, 1914).

Pada tahun 1960-an, seni diklasifikasikan menjadi 2, yaitu secara fungsional, yang lebih terfokus pada tujuannya dimana sebuah karya seni harus mampu menyampaikan nilai estetiknya dan secara prosedural, dimana sebuah karya seni adalah artifak dari seniman yang memahami proses pembuatan karya tersebut.

Sedangkan menurut Ki Hajar Dewantara, seni merupakan perbuatan manusia yang menghasilkan keindahan dan dapat mempengaruhi perasaan seseorang yang melihatnya. Sekarang seni tidak hanya sebagai pemenuh kebutuhan jiwa namun juga kebutuhan hidup, dengan kata lain seni tidak lagi murni sebagai wujud ekspresi jiwa sang pembuatnya. Perkembangan seni di jaman sekarang ini banyak dipengaruhi oleh perkembangan teknologi dan komunikasi. ${ }^{9}$

\section{Creative Art Therapies}

Creative Art Therapies adalah sebuah konsep penggunaan media seni (gambar, lukisan, tarian, dan musik ) untuk terapi psikologis dengan mengkonseptualisasikan tubuh, pikiran, persepsi dan tindakan menjadi satu kesatuan. Konsep seni ini memiliki dampak positif pada stres dan manajemen stress pada diri seseorang, dimana tingkat kecemasan menurun dan mood meningkat.Penerapannya memiliki 3 elemen penting, yaitu persepsi, eksplorasi, ekspresi dan kreasi konten artistik. $^{10}$

\section{Digital Art}

Pada tahun 1967, sebuah kegiatan yang dinamakan EAT (Experiment in Art and Technology), dengan tujuan untuk mempromosikan kolaborasi antara seni dan teknologi yang berkembang, menghasilkan serangkaian instalasi dan pertunjukan yang menggabungkan sistem elektronik inovatif, yaitu melalui proyeksi video, proyeksi suara nirkabel, sirkuit listrik

\footnotetext{
${ }^{8}$ Curran, Thomas, Hill, Andrew P., A Meta-Analysis of Birth Cohort Differences from 1989 to 2016. (Washington DC : Psychological Bulletin , 2017)

${ }^{9}$ Margot Lovejoy, Postmodern Currents: Art and Artist in the Age of Electronic Media, (UMI Research Press, 1989)

${ }^{10}$ Sabine C. Koch, dkk, Creative Art Interventions for Stress Management and Prevention, (Behavioral Sciences, 2018), hlm. 2-3
} 
dan Doppler Sonar. ${ }^{11}$ Eksperimen ini menjadi dasar dan memulai era seni digital yang juga dipengaruhi oleh perkembangan teknologi dan digital di masa itu.

Seni digital adalah karya artistik yang menggunakan teknologi digital sebagai bagian dari proses kreatif atau presentasi. ${ }^{12}$ Perkembangan teknologi digital telah mengubah proses dalam berkarya seni dan membuat instalasi seni digital, virtual reality, dan net art diakui sebagai karya seni.

Seni digital dapat dihasilkan seluruhnya menggunakan komputer atau diambil dari sumber lain seperti foto yang dipindai atau diambil menggunakan kamera. ${ }^{13}$ Meskipun secara teknis istilah ini dapat diterapkan pada seni yang dibuat dengan menggunakan media atau proses lain dan hanya dipindai, biasanya istilah seni digital digunakan untuk seni yang telah dimodifikasi secara non-trivia oleh proses komputasi (seperti program komputer, atau sistem elektronik apa pun yang mampu menafsirkan input untuk membuat output); data teks digital dan rekaman audio dan video mentah biasanya tidak dianggap sebagai seni digital, tetapi dapat menjadi bagian dari proyek seni digital, yaitu sebagai bahan yang akan diproses sebelum menjadi seni digital. ${ }^{14}$ Seni digital dapat dipresentasikan secara 2 dimensi atau 3 dimensi dengan menggunakan layar visual elektronik, tergantung media dan sudut proyeksinya.

\section{Museum}

Museum adalah sebuah bangunan untuk menyimpan koleksi benda-benda untuk inspeksi, studi dan kepuasan, yang dapat berasal darimana saja, dari masa lalu maupun dari masa sekarang, buatan manusia maupun berasal dari alam, dan sebagainya. ${ }^{15}$ Menurut kamus besar Bahasa Indonesia museum berarti: 1). Gedung yang digunakan sebagai tempat untuk pameran tetap benda-benda yang patut mendapat perhatian umum, contohnya seperti peninggalan sejarah, seni dan ilmu). Tempat penyimpanan barang kuno. Sedangkan menurut International Council of Museums, museum adalah sebuah institusi non profit dan bersifat permanen dalam pelayanan untuk komunitas dan terbuka untuk publik, yang berfungsi untuk konservasi, riset, komunikasi dan pameran warisan manusia dan lingkungannya yang berwujud ataupun tidak berwujud. Museum memiliki tujuan untuk edukasi, belajar dan kesenangan. Menurut asal kata museum berasal dari bahasa latin, yaitu mouseion yang berarti tempat yang didedikasikan untuk merenung dan digunakan untuk belajar.Sehingga dapat disimpulkan bahwa museum berarti sebuah bangunan yang digunakan untuk menyimpan atau memamerkan suatu objek yang dapat berwujud maupun tidak berwujud dengan tujuan untuk edukasi dan kesenangan atau kepuasan.

\section{Sejarah Perkembangan Tipologi Museum}

Kegiatan mengoleksi barang-barang antik dan berharga sudah ada sejak jaman dahulu dan kegiatan ini umumnya dilakukan oleh masyarakat kalangan atas pada jaman itu, yaitu keluarga kerajaan $^{16 .}$

Pada abad pertengahan (abad ke- 5 - 15), koleksi-koleksi seni umumnya disimpan di istana dan penyimpanan gereja dan mulai banyak terjadi perdagangan barang koleksi di seluruh dunia. Di masa ini, kata museum pertama kali digunakan dan berarti barang-barang bersejarah dan antik yang digantung di dinding, plafon, serta lemari,yang dimaksudkan untuk memberikan kesenangan dan kepuasan.

Pada akhir abad ke-17 mulai bermunculan museum-museum yang dibuka beberapa hari untuk publik.

\footnotetext{
${ }^{11}$ Michael Zurakhinsky, Digital Art History and Concept, https://www.theartstory.org, diakses tanggal 12 Januari 2019

${ }^{12}$ Christiane Paul, Digital Art, (London : Thames \& Hudson, 2006), hlm. 7-8

13 Ibid, hlm. 26-27

${ }^{14}$ Wands, Bruce, Art of the Digital Age, (London : Thames \& Hudson, 2006), hlm. 10-11.

${ }^{15}$ Allan A. Douglas, The Organization of Museums : Practical Advice Chapter I : The Museum and Its Functions, (Paris : UNESCO, 1960), hlm. 13

${ }^{16}$ Y.M. Manssour, H.M. El Daly, N. K. Morsi, The Historical Evolution of Museum
} 
Pada abad ke-19, perkembangan museum di Eropa berhubungan erat dengan industrialisasi yang sedang berkembang saat itu. Museum banyak dipengaruhi oleh perang dunia pertama dan ke-2, museum menjadi lebih bebas dan independent. Kemudian muncul tren arsitektur baru di masa itu, dimana arsitek berlomba-lomba membuat bangunannya menjadi landmark, yang didukung kemajuan teknologi dan struktur. Sehingga, banyak jenis museum baru yang bermunculan, serta banyak fungsi ruang museum yang baru seperti lab, workshop, perpustakaan, conference hall, restoran, café dan toko souvenir.

Pada abad ke-21, dunia arsitektur menjadi lebih maju dengan penggunaan teknologi yang lebih maju pada tahap desain, dimana muncul cara baru untuk menampilkan karya seni, teknik pencahayaan yang berbeda, sampai adanya kunjungan virtual. Pengunjung dapat berinteraksi dengan karya seni dan pengalaman yang dirasakan lebih dekat dan langsung.

\section{Perkembangan Museum di Masa Depan}

Museum ke depannya di masa depan akan berkembang menjadi sebuah akomodasi yang aktif, digerakkan oleh teknologi dan memberi pengalaman baru yang berbeda, dimana museum akan menjadi lebih interaktif dan bersifat self-directed. ${ }^{17}$

Desain museum yang sebelumnya ikonik akan berubah menjadi lebih welcoming, public oriented dan fleksibel, yang beraarti museum akan lebih mudah diakses publik, experience based dan objek yang dipamerkan bersifat lebih dinamis. ${ }^{18}$ Desain museum ini merefleksikan perubahan yang terjadi pada seni, pendidikan dan tujuan dari museum itu sendiri terhadap masyarakat di masa depan.

Museum akan dituntut untuk menjadi menyenangkan, menimbulkan rasa ingin tahu, memungkinkan pengunjung untuk melihat keindahan, dan keajaiban serta diposisikan untuk memadukan pendidikan dan rekreasi. ${ }^{19}$ Pengunjung akan memiliki interaksi yang lebih dalam dengan objek yang dipamerkan dan menstimulasi ke-5 indera yang dimiliki oleh manusia.

\section{Standar Kebutuhan Lahan Museum}

Pemilihan lokasi museum sangat bervariasi karena museum dapat dibangun di tengah kota maupun di pinggiran kota dengan kelebihan dan kekurangannya masing-masing. Museum harus dapat di akses dari seluruh bagian kota dengan transportasi publik dan jika memungkinkan ada dalam jangkauan pejalan kaki yang nyaman serta mudah dijangkau dari sekolah, universitas dan perpustakaan. ${ }^{20}$ Lingkungan di sekitar tapak museum harus memiliki ruang kosong untuk perpanjangan museum ke depannya serta menyediakan ruang untuk parkir kendaraan.

\section{Standar Kebutuhan Ruang}

Tabel 1. Tabel Kebutuhan Ruang

\begin{tabular}{|c|c|}
\hline Fungsi & Kebutuhan Ruang \\
\hline $\begin{array}{l}\text { 1. Fungsi Kuratorial } \\
\text { a. Koleksi, preservasi, identifikasi } \\
\text { dokumentasi, restorasi. } \\
\text { b. Penyimpanan koleksi. }\end{array}$ & $\begin{array}{l}\text { a. Ruang kerja, workshop } \\
\text { b. Ruang penyimpanan koleksi }\end{array}$ \\
\hline $\begin{array}{l}\text { 2. Fungsi Pameran } \\
\text { Pameran tematik dan berubah-ubah yang } \\
\text { dipilih serta dokumen dari koleksi yang } \\
\text { disusun untuk menceritakan sesuatu. }\end{array}$ & Galeri objek pameran \\
\hline $\begin{array}{l}\text { 3. Fungsi Persiapan Pameran } \\
\text { Persiapan dari pameran-pameran yang ada }\end{array}$ & Bengkel kerja/workshop, kantor-ruang kerja \\
\hline
\end{tabular}

\footnotetext{
${ }^{17}$ Museum Futures, Gentler Research, 2015, hlm. 2-3

18 Ibid.

${ }^{19} \mathrm{Ibid}, \mathrm{hlm} .4$

${ }^{20}$ Ibid. hlm. 329
} 


\section{Fungsi Edukasional dan Publik}

a. Seminar, tur sekolah, pertemuan komunitas, dan fungsi-fungsi sosial lainnya.

b. Penerimaan, informasi, penjualan, dan pengawasan.

c. Kebutuhan publik.

$\begin{array}{ll}\text { 5. Servis lainnya } & \text { a. Ruang genset dan mesin AC } \\ \begin{array}{l}\text { a. Mekanikal } \\ \text { b. Janitorial }\end{array} & \text { b. Ruang ganti petugas kebersihan }\end{array}$

Sumber: Time Saver Standards for Building Types, 1980

\section{Standar Organisasi Ruang}

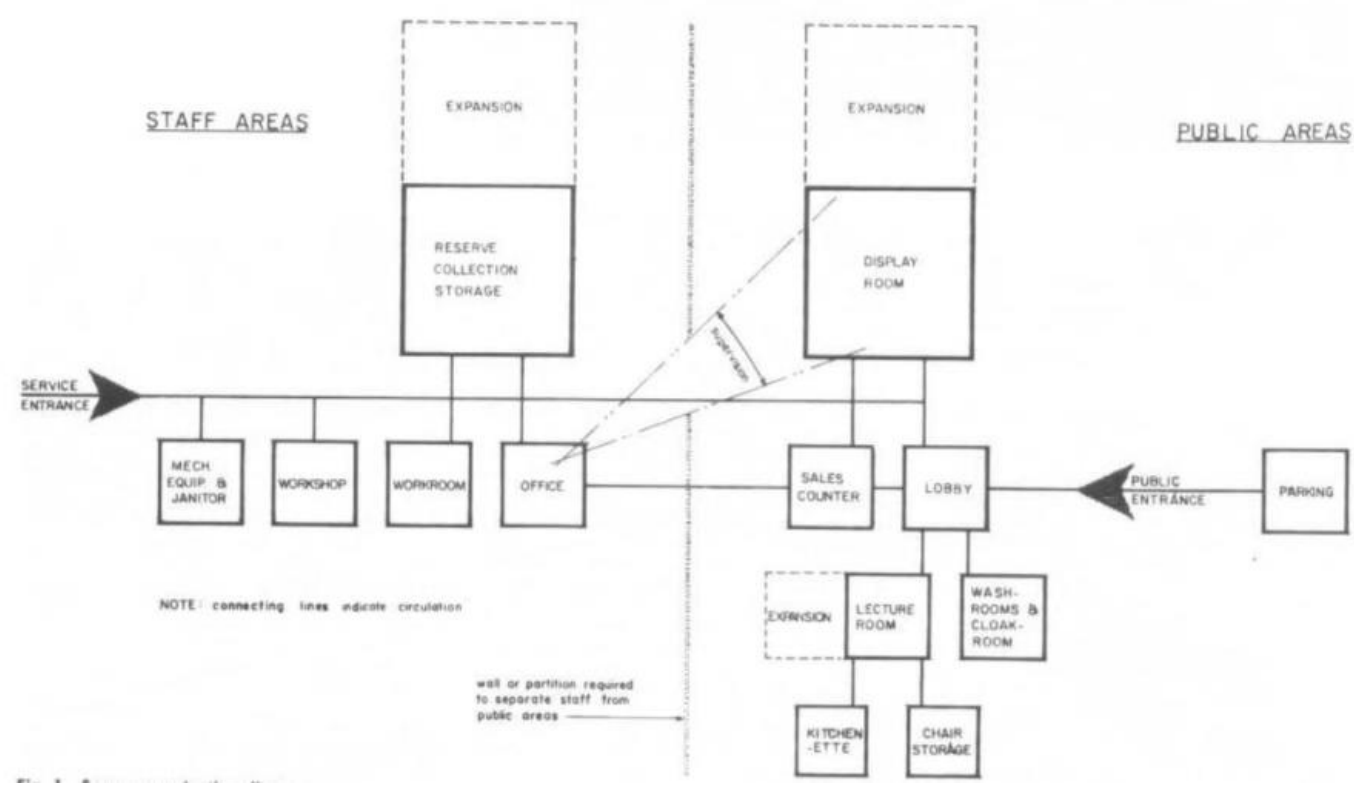

Gambar 3. Diagram Organisasi Ruang Museum

Sumber: Time Saver Standards for Building Types

Organisasi ruang pada museum secara umum dibagi menjadi 5 area, yaitu:

1. Zona publik tanpa koleksi : Lobby, loket informasi dan tiket, ruang penitipan barang, ruang seminar, ruang penyimpanan kursi seminar.

2. Zona publik dengan koleksi : Ruang pameran

3. Zona staff tanpa koleksi : Janitor, ruang mekanikal, kantor

4. Zona staff dengan koleksi : Bengkel kerja

5. Zona Penyimpanan Koleksi : Ruang penyimpanan koleksi

\section{Standar Ruang Pameran}

Ruang pameran memerlukan ruang dinding yang lebih luas dibandingkan luas lantainya. Ruang pameran harus merupakan ruang dengan lingkungan visual yang murni tanpa kekacauan. Elemen pembentuk ruang pameran harus bersifat fleksibel agar dapat diatur menyesuaikan setiap pameran yang diadakan. Dinding display dengan tinggi minimal 12 kaki diperlukan bagi sebagian besar museum seni, namun museum untuk seni kontemporer harus memiliki langit-langit yang lebih tinggi, yaitu minimal 20 kaki, untuk mencapai ketinggian yang bersifat fleksibel. ${ }^{21}$ 


\section{METODE}

Metode desain yang digunakan di dalam perancangan ini adalah riset untuk studi karakter generasi milenial dan menganalisa masalah, kebutuhannya, serta kaitannya pada perkembangan tipe museum di masa ini, kemudian studi preseden untuk menstudi karakter museum, organisasi ruang dan zoning di dalam museum yang menjadi landasan dalam studi bentuk massa, kemudian yang terakhir adalah metode shape grammar untuk menstudi bentuk massa. Shape grammar adalah sistem dalam membuat grafis yang menyediakan mekanisme untuk menghasilkan komposisi berdasarkan bentuk dan hubungan spasial dengan menentukan metode untuk mengganti bagian-bagian bentuk dasar satu dengan yang lainnya. (Liew, Haldane, 2002). Bentuk dasar yang digunakan adalah bentuk dasar ruang pameran di dalam museum yaitu kotak dengan ukuran $8 \mathrm{~m} \times 8 \mathrm{~m}$ serta menggunakan aturan bentuk penambahan dan pemutaran untuk menemukan kemungkinan-kemungkinan hubungan spasial yang mungkin terjadi.

\section{DISKUSI DAN HASIL}

Berdasarkan hasil riset mengenai karakter generasi milenial, dapat disimpulkan bahwa generasi milenial memiliki karakter experience seeker, explorer, dan ekspresif. Sehingga pengalaman ruang dimana pengunjung dapat mengeksplor ruang secara bebas dan menarik menjadi karakter ruang yang dibutuhkan.

Proyek "Digital Art Museum" ini akan memenuhi kebutuhan penduduk berupa hiburan yang mendidik, menarik dan atraktif diperuntukkan untuk semua golongan masyarakat, terutama yang berusia produktif. Karena itu bangunan yang tercipta ramah penyandang disabilitas dan ramah pejalan kaki.

Museum terdiri dari ruang pameran tetap dan tidak tetap atau sementara. Pameran tidak tetap mempertunjukkan objek yang berasal dari instansi lain, sedangkan pameran tetap terdiri dari beberapa ruang yang dibedakan dari media yang digunakan untuk menampilkan seni digital, yaitu media berupa layar atau dinding dan lantai, media berupa suatu instalasi dan media yang melibatkan pengunjung berkontribusi dalam terbentuknya seni digital dengan teknik computer generated images.

\section{Programatik}

Di era digital ini dengan perkembangan teknologi yang terus berkembang pesat, batas antara dunia digital dengan dunia nyata semakin kabur dan seolah tidak memiliki batas. Dunia tanpa batas ini memberikan pengalaman baru untuk generasi sekarang dan generasi yang akan datang, mengeksplor berbagai hal, terutama dalam konteks seni.

Digital Art Museum ini akan menjadi wadah generasi muda di jaman sekarang dan di jaman yang akan datang mengeksplor dunia tanpa batas dan mengkespresikan dirinya dalam bentuk seni.

Untuk mewujudkan kebutuhan ruang berdasarkan karakter generasi milenial, desain akan terfokus pada pengalaman ruang yang membuat pengunjung dapat mengkesplor berbagai karya seni secara bebas dan memunculkan berbagai kemungkinan pengalaman yang berbeda, sehingga alur yang diterapkan adalah unlinear. Kemudian pameran tetap akan dibagi menjadi 3 zona berdasarkan sifatnya, yaitu:

a. Immersive Digital Art, dimana karya seni akan menggunakan elemen bangunan sebagai medianya (dinding dan lantai)

b. Athletic Digital Art, dimana karya seni akan mendorong interaksi antar pengunjung dengan karya seni tersebut melalui interaksi secara fisik.

c. Co-create Digital Art, dimana pengunjung dapat berkontribusi dalam terciptanya karya seni dan menerapkan creative art intervention ke dalam aktivitas tersebut. 
Tabel 2. Program Ruang

\begin{tabular}{|c|c|c|c|}
\hline Ruang & Sub Ruang & Aktivitas & $\begin{array}{l}\text { Persentase } \\
\text { Ruang (\%) }\end{array}$ \\
\hline \multirow{10}{*}{ Penerimaan } & Lobby & Berkumpul & \multirow{10}{*}{$9.05 \%$} \\
\hline & Information & Menanyakan informasi mengenai museum & \\
\hline & $\begin{array}{l}\text { Tempat pembelian } \\
\text { tiket masuk }\end{array}$ & $\begin{array}{l}\text { Mengantri dan jual beli tiket manual/konfirmasi e- } \\
\text { ticket }\end{array}$ & \\
\hline & $\begin{array}{l}\text { Tempat penitipan } \\
\text { barang }\end{array}$ & Menyimpan barang di loker & \\
\hline & WC laki-laki & Cuci tangan, buang air kecil dan besar & \\
\hline & WC perempuan & Cuci tangan, buang air kecil dan besar & \\
\hline & WC disable & Cuci tangan, buang air kecil dan besar & \\
\hline & Janitor & Menyimpan alat bersih-bersih & \\
\hline & R. laktasi & Menyusui anak & \\
\hline & mushola & Sholat & \\
\hline \multirow{5}{*}{ Pameran } & $\begin{array}{l}\text { R. pameran seni } \\
\text { digital imersif }\end{array}$ & $\begin{array}{l}\text { Pameran seni digital yang bersifat imersif dengan } \\
\text { media layar/dinding/lantai dan teknik computer } \\
\text { generated images }\end{array}$ & \multirow{5}{*}{$41.19 \%$} \\
\hline & $\begin{array}{l}\text { R. pameran seni } \\
\text { digital co-create }\end{array}$ & $\begin{array}{l}\text { Pameran seni digital yang mengajak keikutsertaan } \\
\text { pengunjung dalam terbentuknya karya seni }\end{array}$ & \\
\hline & $\begin{array}{l}\text { R. pameran seni } \\
\text { digital interaktif }\end{array}$ & $\begin{array}{l}\text { Pameran seni digital dengan media instalasi dan } \\
\text { teknik computer generated images }\end{array}$ & \\
\hline & $\begin{array}{l}\text { R. pameran } \\
\text { temporer }\end{array}$ & $\begin{array}{l}\text { Pameran yang bersifat temporer, seperti digital } \\
\text { painting, vector drawing, dsb yang diluar teknik } \\
\text { computer generated images }\end{array}$ & \\
\hline & R.pameran outdoor & $\begin{array}{l}\text { Pameran seni digital yang dipadukan dengan } \\
\text { elemen alam }\end{array}$ & \\
\hline \multirow{7}{*}{$\begin{array}{l}\text { Fasilitas } \\
\text { Pendukung }\end{array}$} & Toko souvenir & Jual beli souvenir museum & \\
\hline & Café : & & \\
\hline & Area duduk & Makan, minum, berkumpul & \multirow{5}{*}{$18.21 \%$} \\
\hline & Dapur & Menyiapkan makanan dan minuman & \\
\hline & Gudang Café & Menyimpan bahan makanan, minuman, wadah, dll & \\
\hline & R. Multifungsi & Seminar, pertunjukkan, open discussion, workshop & \\
\hline & $\begin{array}{l}\text { Open public space } \\
\text { (plaza) }\end{array}$ & Istirahat, berkumpul dan berinteraksi & \\
\hline \multirow{5}{*}{$\begin{array}{l}\text { Kantor } \\
\text { Pengelola }\end{array}$} & R. Direktur & Mengelola segala sesuatu terkait museum & \multirow{5}{*}{$5.24 \%$} \\
\hline & R.Karyawan Divisi Pa & eran dan Perencanaan, yang terdiri dari : & \\
\hline & - R. Kurator & Mengkurasi karya seni & \\
\hline & $\begin{array}{l}\text { - R. Exhibition } \\
\text { management }\end{array}$ & $\begin{array}{l}\text { Mengatur teknis dan jadwal karya seni yang } \\
\text { ditampilkan }\end{array}$ & \\
\hline & $\begin{array}{l}\text { - R. Education \& } \\
\text { public program }\end{array}$ & $\begin{array}{l}\text { Merencanakan program tambahan museum untuk } \\
\text { publik yang bersifat edukatif seperti workshop, } \\
\text { seminar dan talkshow }\end{array}$ & \\
\hline
\end{tabular}




\begin{tabular}{|c|c|c|c|}
\hline & - R. humas \& HRD & $\begin{array}{l}\text { Mengatur segala hal terkait relasi internal- } \\
\text { eksternal serta SDM }\end{array}$ & \\
\hline & $\begin{array}{l}\text { - R. administrasi \& } \\
\text { keuangan }\end{array}$ & Mengurus administrasi dan keuangan museum & \\
\hline & - R. IT & $\begin{array}{l}\text { Mengatur dan memperbaiki sistem di dalam } \\
\text { museum }\end{array}$ & \\
\hline & R. server & $\begin{array}{l}\text { Mengatur server yang menghubungkan komputer } \\
\text { dengan proyektor yang menampilkan karya seni di } \\
\text { r.pameran }\end{array}$ & \\
\hline & R. eksperimen & $\begin{array}{l}\text { Melakukan trial and error untuk pameran yang } \\
\text { akan datang }\end{array}$ & \\
\hline & R. rapat 1 & Berdiskusi dan memutuskan pendapat & \\
\hline & R. rapat 2 & Berdiskusi dan memutuskan pendapat & \\
\hline & R. arsip & Menyimpan arsip museum & \\
\hline & Pantry & Makan dan minum & \\
\hline & Gudang Kantor & Menyimpan peralatan kantor & \\
\hline \multirow{3}{*}{ Storage } & R. peralatan & Menyimpan peralatan museum, seperti proyektor & \multirow{3}{*}{$5.37 \%$} \\
\hline & $\begin{array}{l}\text { R. penyimpanan } \\
\text { pameran }\end{array}$ & $\begin{array}{l}\text { Menyimpan instalasi yang akan dipamerkan atau } \\
\text { akan dipindahkan keluar museum }\end{array}$ & \\
\hline & $\begin{array}{l}\text { R. penyimpanan } \\
\text { instalasi sementara }\end{array}$ & $\begin{array}{l}\text { Menyimpan instalasi yang rusak dan akan } \\
\text { diperbaiki }\end{array}$ & \\
\hline \multirow{14}{*}{ Servis } & $\begin{array}{l}\text { R. ganti karyawan } \\
\text { (bidang servis } \\
\text { bangunan) laki-laki }\end{array}$ & \multirow{2}{*}{$\begin{array}{l}\text { Menyimpan barang pribadi karyawan dan ganti } \\
\text { pakaian karyawan yang bekerja khusus di bidang } \\
\text { servis, seperti cleaning service, keamanan, dsb }\end{array}$} & \multirow{14}{*}{$6.03 \%$} \\
\hline & $\begin{array}{l}\text { R. ganti karyawan } \\
\text { (bidang servis } \\
\text { bangunan) } \\
\text { perempuan }\end{array}$ & & \\
\hline & Janitor & Menyimpan alat bersih-bersih & \\
\hline & $\begin{array}{l}\text { WC karyawan laki- } \\
\text { laki }\end{array}$ & \multirow{2}{*}{ Cuci tangan, buang air kecil dan besar } & \\
\hline & $\begin{array}{l}\text { WC karyawan } \\
\text { perempuan }\end{array}$ & & \\
\hline & Kantin karyawan & $\begin{array}{l}\text { Menyediakan makanan dan minuman untuk } \\
\text { seluruh karyawan museum }\end{array}$ & \\
\hline & R. AHU & Kontrol dan perbaikan & \\
\hline & R. CCTV & Mengontrol cctv & \\
\hline & R. genset & \multirow{6}{*}{ Kontrol dan perbaikan } & \\
\hline & R. trafo & & \\
\hline & R. panel induk & & \\
\hline & R. pompa & & \\
\hline & GWT & & \\
\hline & STP & & \\
\hline \multirow{3}{*}{ Parkiran } & parkir mobil & $20 \%$ dari total pengguna bangunan & \multirow{2}{*}{$11.47 \%$} \\
\hline & parkir motor & $10 \%$ dari total pengguna bangunan & \\
\hline & sirkulasi kendaraan & $30 \%$ dari total parkiran & $3.44 \%$ \\
\hline Total & & & $100.00 \%$ \\
\hline
\end{tabular}

Sumber: Penulis, 2019 


\section{Organisasi Ruang}

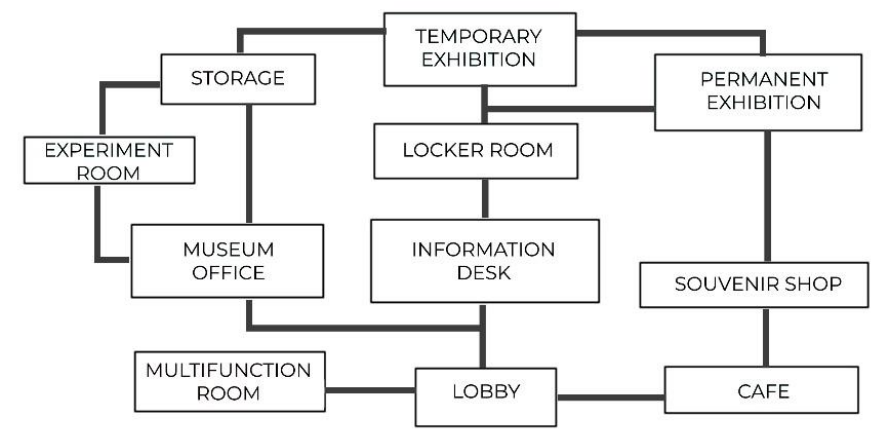

Gambar 43. Organisasi Ruang

Sumber: Olahan Penulis Berdasarkan Acuan dari Gambar 3

\section{Tinjauan Lokasi}

Kriteria Pemilihan Kawasan

1. Jumlah penduduk didominasi generasi millennial yang saat ini merupakan orang dewasa berusia produktif.

2. Memiliki distrik perkantoran dan edukasi yang berdekatan.

3. Pengembangan kawasan berorientasi pada perkembangan teknologi dan jaman, seperti kota ramah lingkungan dan smart city, yang menjadi concern generasi millennial.

Analisa Makro
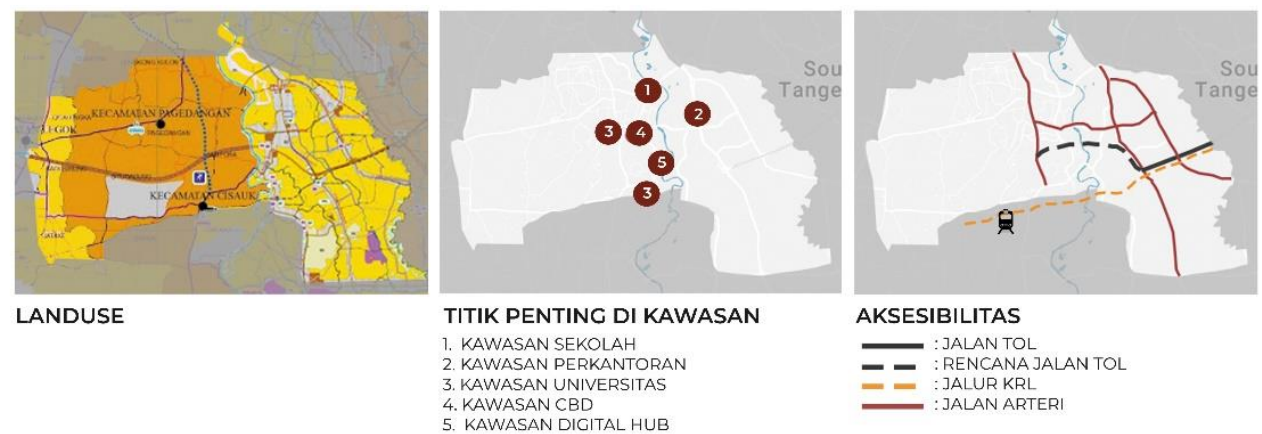

Gambar 5. Pemetaan Kawasan untuk Analisa Makro

Sumber: Penulis, 2019

Kawasan kota Bumi Serpong Damai atau yang sering disebut dengan BSD City merupakan salah satu kota satelit Jakarta dengan luas sebesar $6000 \mathrm{Ha}$ yang direncanakan menjadi pionir Integrated Smart Digital City dan pusat pengembangan talenta digital, dimana terdapat sekolah-sekolah IT serta kantor-kantor yang bergerak khusus di bidang teknologi (Digital Hub) yang dipengaruhi oleh jumlah penduduk BSD City (tahun 2017) mencapai 207.172 jiwa yang didominasi anak-anak dan orang dewasa berusia produktif.

Kawasan BSD City sebagian besar peruntukkan lahannya adalah zona pemukiman dengan zona perkantoran berada di pusat dan perdagangan menyebar diantara zona pemukiman. Jalan utama kawasan berada di pusat yang menghubungkan kawasan BSD dengan kawasan Gading Serpong dan Cisauk. Di sepanjang jalan utama dikembangkan Central Business District dan Edutown. Akses menuju Jakarta dan sebaliknya jika menggunakan kendaraan roda empat atau lebih, melalui tol Jakarta-Serpong yang berada $\pm 5 \mathrm{~km}$ dari pusat kawasan, sedangkan jika menggunakan kendaraan umum terdapat KRL Commuter Line jalur Serpong yang berhenti di stasiun Rawa Buntu, Serpong, Cisauk dan Cicayur. Stasiun Cisauk terletak $\pm 3 \mathrm{~km}$ dari pusat kawasan dan terintegrasi langsung dengan terminal bus intermoda yang menghubungkan ke beberapa titik di dalam kawasan BSD City. Titik penting kawasan BSD City terdiri dari Business District serta kawasan pendidikan. Titik-titik penting ini berada di pusat. 


\section{Analisa Makro}
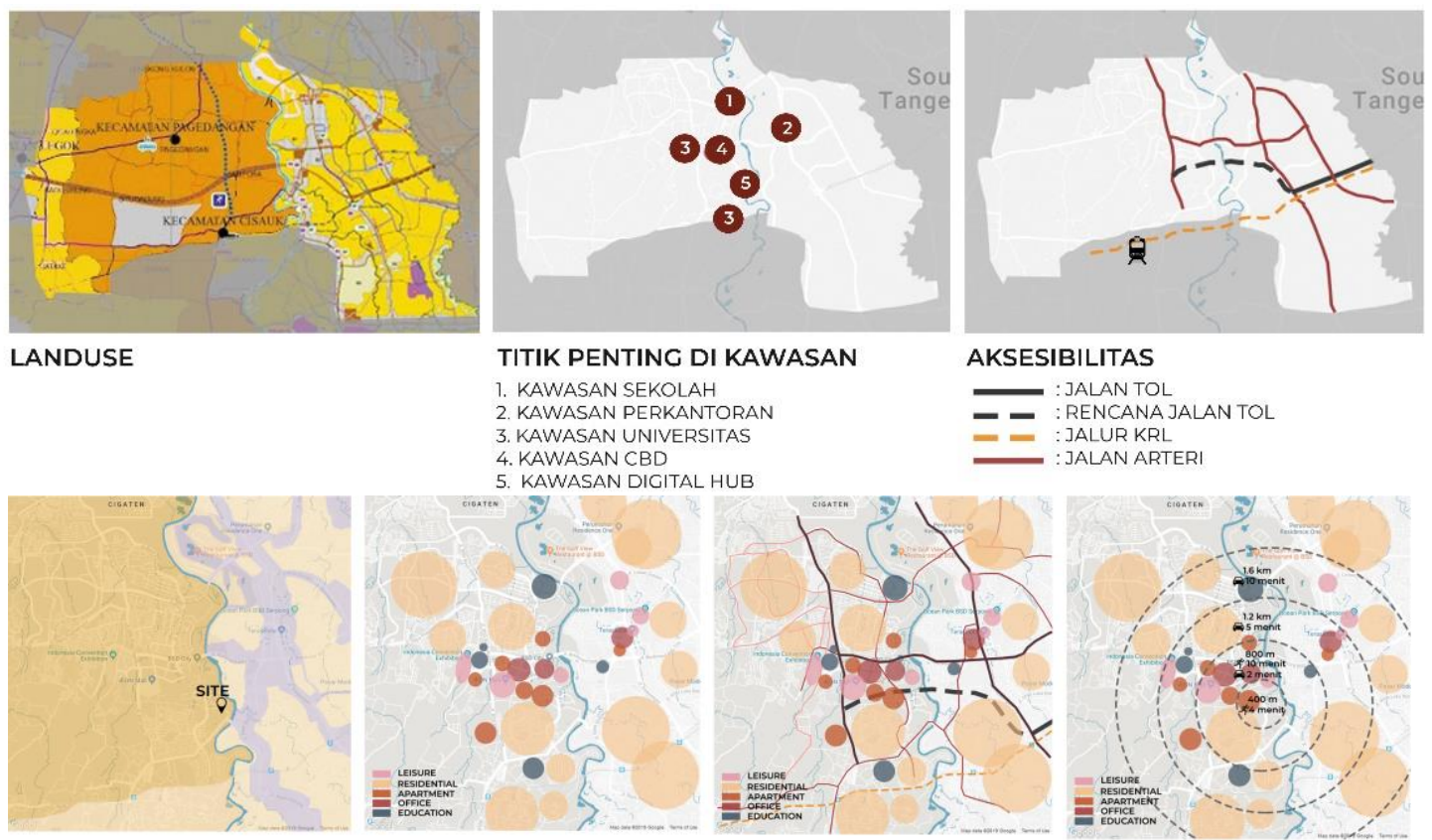

EXISTING LANDUSE

TITIK PENTING DI KAWASAN

1. KAWASAN SEKOLAH

2. KAWASAN PERKANTORAN

3. KAWASAN UNIVERSITAS

4. KAWASAN CBD

5. KAWASAN DIGITAL HUB

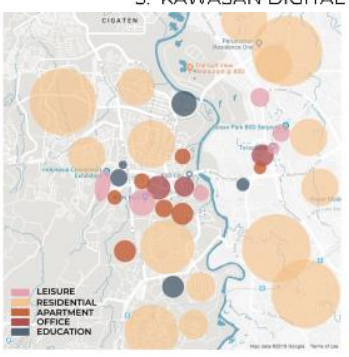

FUTURE FUNCTION

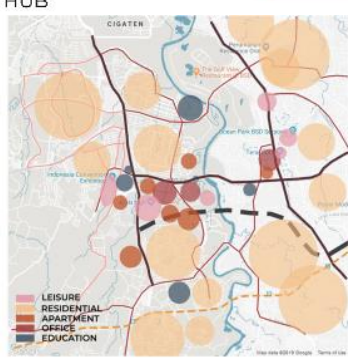

ROAD HIERARCHY
AKSESIBILITAS

: JALAN TOL

- - : RENCANA JALAN TOL

- $=$ :JALUR KRL : JALAN ARTERI

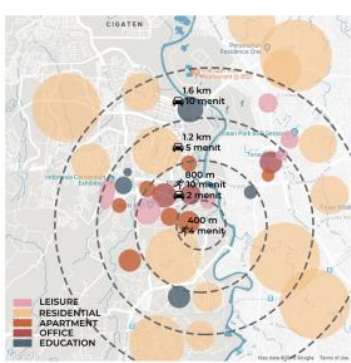

ACCESSIBILITY

Gambar 6. Pemetaan Kawasan untuk Analisa Kawasan Sumber: Penulis, 2019

Berdasarkan hasil analisa diketahui bahwa pusat kawasan memiliki distrik perkantoran dan edukasi yang berdekatan dan merupakan titik penting dari kawasan, sehingga area pusat menjadi fokus pemilihan tapak.

Jalan utama menghubungkan BSD City dengan Gading Serpong, Bintaro dan Cisauk. Pusat BSD City berada di persilangan antara 3 jalan utama dan pada pusatnya terdapat kawasan perkantoran, apartment, edukasi serta fasilitas pendukung seperti mall dan pasar. Pusat kota memiliki tingkat kepadatan yang tinggi dan diperuntukkan untuk bangunan-bangunan tinggi.

\section{Kriteria Pemilihan Tapak}

- Berada di dekat titik pemberhentian $B R T$, untuk memudahkan pencapaian dari luar ke tapak maupun sebaliknya.

- Berada di dekat kawasan Central Business District dan Digital Hub, yang penggunanya didominasi generasi millennial, yang merupakan target pengguna.

- Berada di dekat kawasan pusat pendidikan (edutown), agar dapat mendukung fasilitas pendidikan didalamnya.

- Tingkat kepadatan bangunan sekitar rendah atau sedang, agar tidak merusak skyline dan wajah kota.

- Berada di nodes, agar museum dapat berpotensi menjadi landmark kawasan. 


\section{Analisa Mikro}

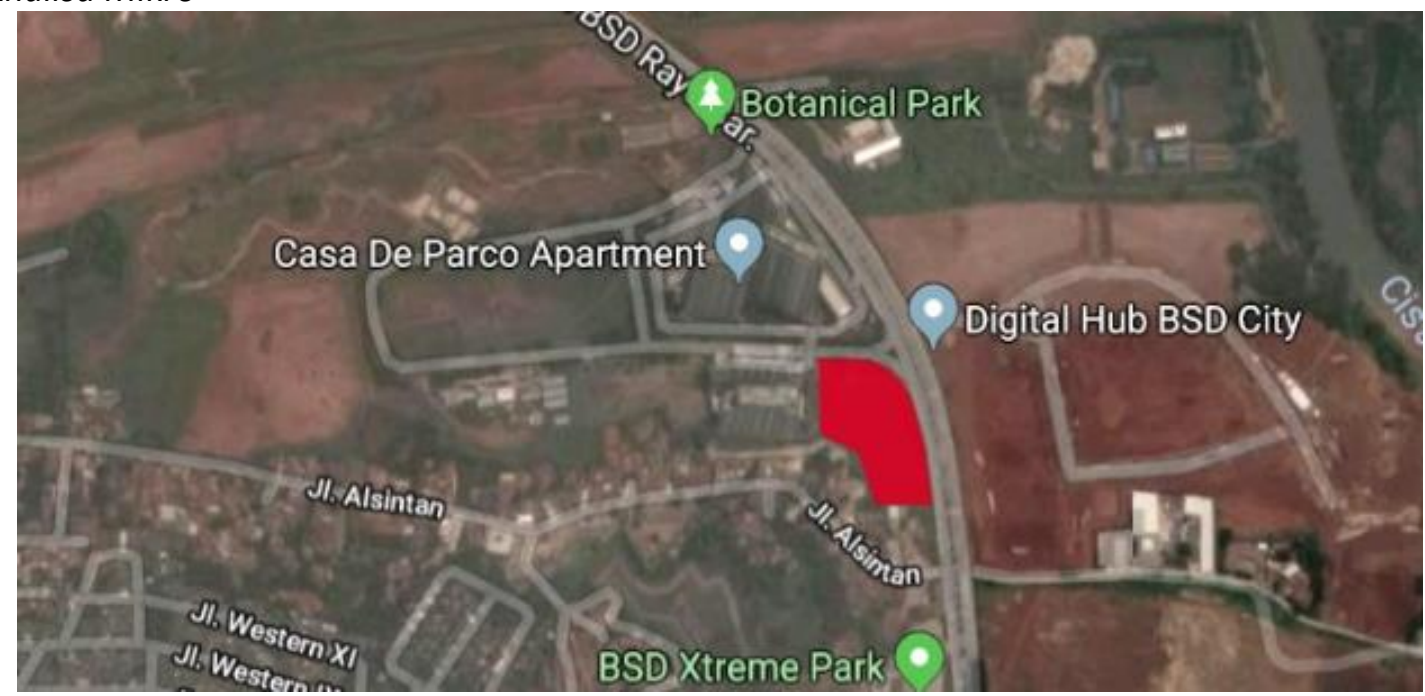

Gambar 7. Lokasi Tapak

Sumber: Google Images

Tapak terletak di jalan BSD Raya Barat dengan luasan $8.712 \mathrm{~m}^{2}$ dan sisi utara menghadap Casa de Parco Shophouse dan Apartment, sisi Barat menghadap Saveria Apartment, sisi Selatan menghadap rumah-rumah warga, serta sisi Timur menghadap Digital Hub. Peruntukkan lahannya adalah pemukiman dengan kegiatan yang diperbolehkan meliputi perumahan dan kegiatan yang mendukung pemukiman dengan KDB 50-60\%, KDH 10\%-30\% dan KB 1-20.

Tapak memiliki kelebihan mudah di akses karena terletak di nodes dan dekat dengan bus stop $(100 \mathrm{~m})$, berada di seberang digital hub dan dekat dengan kawasan pendidikan kota BSD. Tapak memiliki peluang ramai pengunjung karena sistem TOD dan keadaan jalur pedestrian yang tertata baik dan letaknya yang strategis dapat menarik pengunjung masuk ke dalam tapak.Kekurangan pada tapak adalah bersebelahan dengan rumah-rumah warga yang kurang teratur dan viewnya kurang bagus.

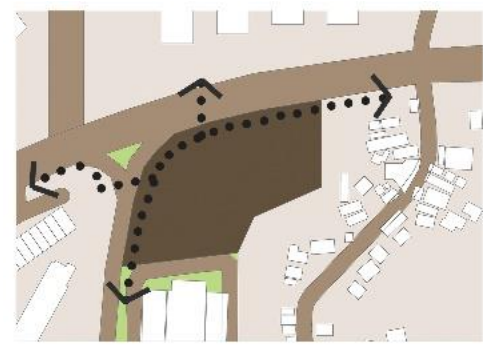

PEDESTRIAN MOVEMENT

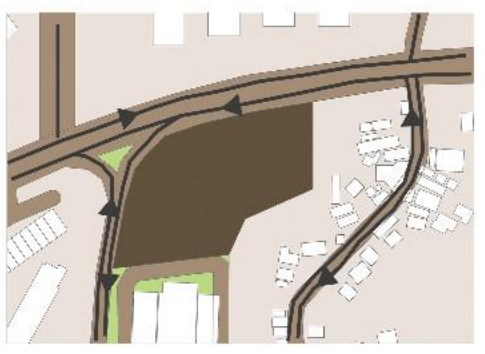

VEHICLE MOVEMENT

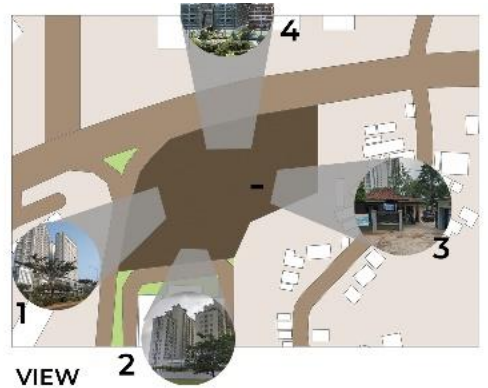

Gambar 8. Pemetaan Kawasan untuk Analisa Mikro

Sumber: Penulis, 2019 


\section{Massa Bangunan}

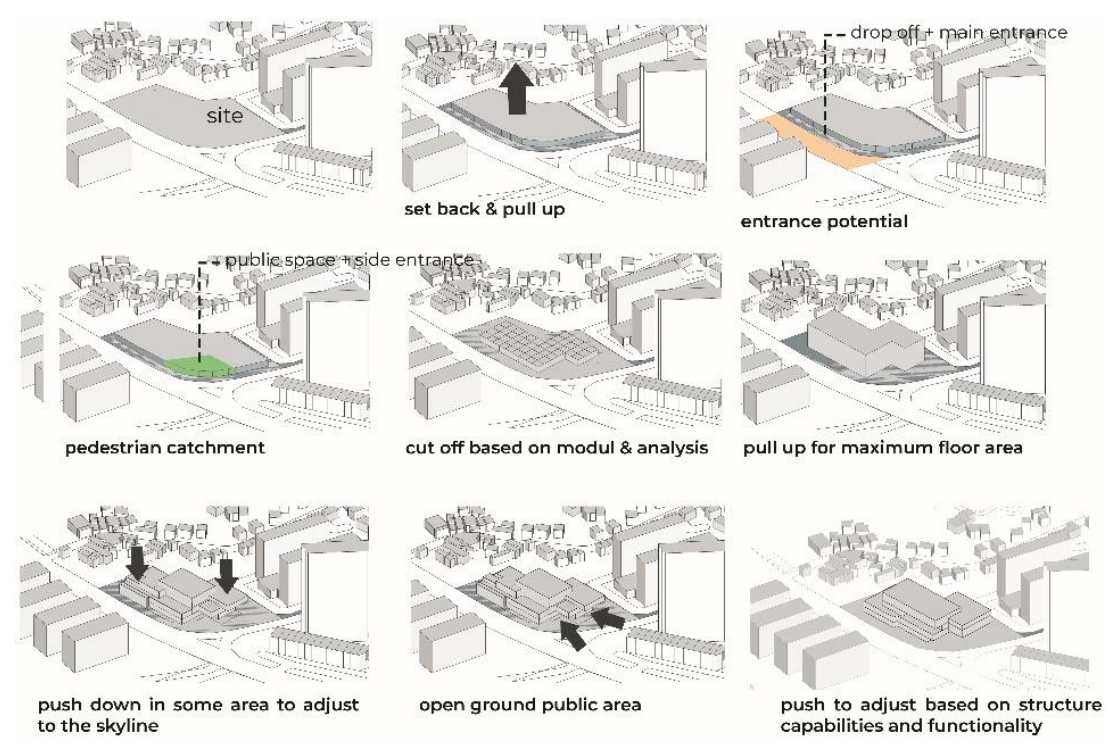

Gambar 9. Proses Gubahan Massa

Sumber: Penulis, 2019

Massa dibentuk berdasarkan bentuk tapak dan area nodes dipotong menciptakan ruang terbuka publik untuk menarik pengunjung dengan pintu masuk utama menghadap Jalan BSD Raya Barat. Kemudian massa dibentuk dengan modul yang disesuaikan dengan ruang pameran dan parkiran. Massa dibuat terpusat hanya 1 massa yang semakin ke atas semakin mengecil dan meninggi ke atas.

Pintu masuk utama di Timur yang menghadap Jalan BSD Raya Barat diutamakan untuk pejalan kaki, pengguna sepeda dan pengunjung bergrup yang menggunakan bus, sehingga jalur masuk-keluar serta drop off mobil dipusatkan di sisi Barat tapak. Kemudian untuk sisi selatan yang berbatasan dengan rumah-rumah warga sekitar digunakan untuk jalur servis dan masukkeluar motor.

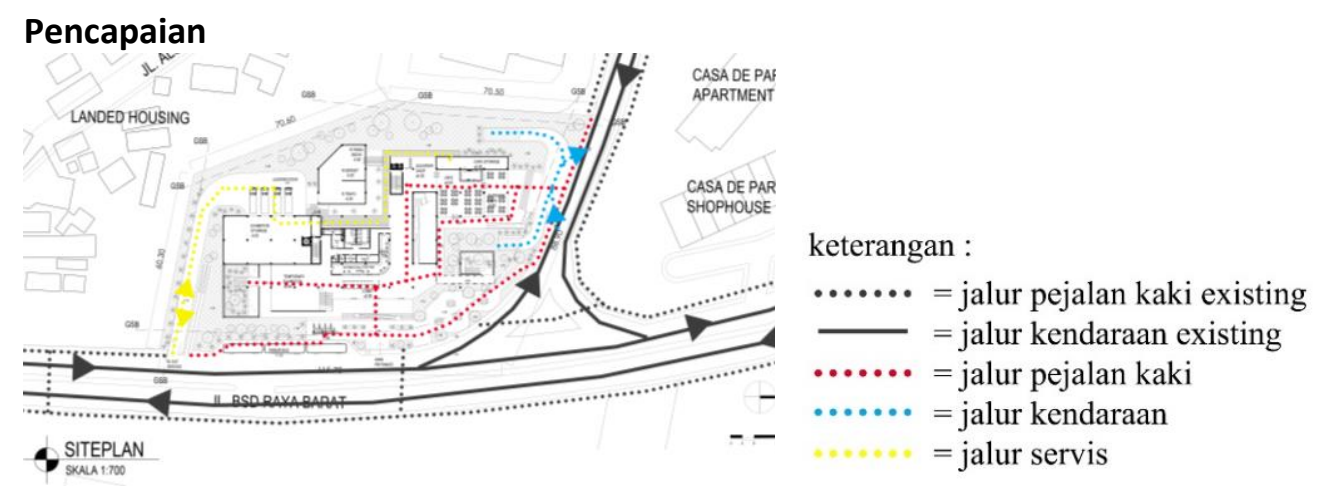

Gambar 10. Skema Pencapaian

Sumber: Penulis, 2019

Lantai dasar dibuat transparan karena bersifat publik dan terdapat kantilever yang melindungi pengunjung yang berjalan di teras dari hujan. Ruang terbuka publik dibuat senyaman mungkin dengan banyaknya vegetasi, pohon serta area duduk dan terlihat menerus dengan trotoar untuk menarik pejalan kaki masuk ke dalam tapak. Ruang terbuka publik 
tersebut dapat digunakan juga untuk pengunjung berkumpul sebelum atau setelah mengujungi museum dan beristirahat. Lantai dasar difungsikan untuk publik, yaitu terdapat resepsionis, café, souvenir shop, dsb, serta untuk servis, yaitu untuk loading dock dan ruang penyimpanan.
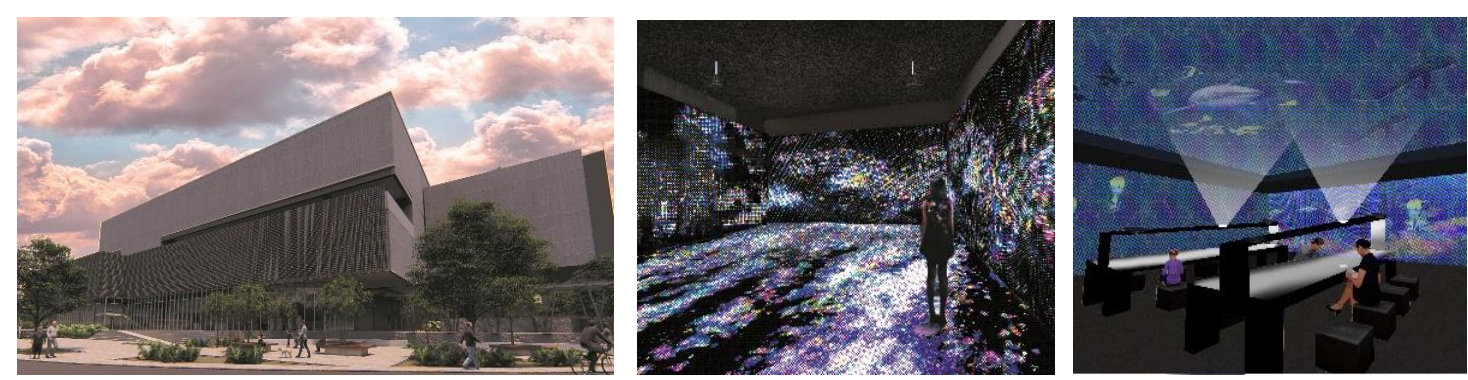

Gambar 11. Gambar Perspektif Ruang Dalam dan Ruang Luar Sumber: Penulis, 2019

Pameran tetap berada di lantai 2-4 museum dengan sirkulasi utama menggunakan ramp dan lift karena fokus pada bangunan yang ramah terhadap penyandang disabilitas. Fasad dibuat sesederhana mungkin, namun tetap menarik, yaitu dengan adanya zero energy LED screen yang digerakkan dengan energi matahari dan menampilkan informasi mengenai museum serta karya seni digital yang dapat menarik orang-orang yang melalui jl. BSD Raya Barat untuk mengunjungi museum.

\section{KESIMPULAN DAN SARAN}

Karakter generasi millenials yang dinamis, fleksibel dan suka mencari pengalaman yang unik dan menarik menjadi dasar dari perancangan museum seni digital, terutama membentuk zona ruang pameran tetap yang fokus pada eksplorasi secara bebas (Immersive Digital Art), serta memicu interaksi antar pengunjung dan antara pengunjung dengan karya seni yang dipamerkan (Athletic Digital Art \& Co-create Digital Art). Museum seni digital menjadi wadah dimana generasi millennial dapat mengisi waktu luang dan mengurangi tingkat stress yang dirasakan dari rutinitas sepanjang hari. Studi terhadap karakter generasi yang akan datang dapat menjadi bahan pertimbangan terhadap perkembangan museum kedepannya.

\section{REFERENSI}

Berger, A.A. (2018). Cultural Perspectives on Millennials, London: Palgrave Macmillan.

Chiara, J. D. \& Callender, J. Time Saver Standards for Building Types, (Mc Graw Hills Inc., 1980) hlm. 329

Curran, Thomas,Hill, Andrew P. (2017). A Meta-Analysis of Birth Cohort Differences from 1989 to 2016. Washington DC : Psychological Bulletin.

Douglas, Allan A. (1960). The Organization of Museums : Practical Advice Chapter I: The Museum and Its Functions, Paris : UNESCO.

Gentler Research. (2015) Museum Futures.

Grigorenko (Ed.). (2015). The global context for new directions for child and adolescent development. New Directions for Child and Adolescent Development.

Kusumaputra, R.A. Serpong Kota Baru yang Gemerlap dan Memikat. diakses tanggal 12 Januari 2019 dari https://interaktif.kompas.id/serpong

Jarvin, L.., Edutainment, games, and the future of education in a digital world. (E. L.)

Joudrey, A.D. \& Wallace, J.E. (2009). Leisure as a Coping Resource: A Test of the Job Demand Control Support Model, Human Relations. 
Koch, S.C., dkk. (2018) Creative Arts Interventions for Stress Management and Prevention, USA: Behavioral Science.

Koch, S.C., \& Fuchs T. (2011). Embodied Arts Therapies, Arts Psychother.

Krauss. (2012). Recreational \& Leisure in Modern Society.

L. Margot. (1989) Postmodern Currents: Art and Artist in the Age of Electronic Media, UMI Research Press.

Molnar, A. R. \& Deringer, D. K. (1984). Edutainment: How to learn to laugh and learn, IEEE Spectrum.

T. Gunawan. (2000) Metode Perancangan Suatu Pengantar untuk Arsitek dan Perancang, Depok : UI.

Yamamoto, M. \& Watanabe, T. (2013). Development of an edutainment system with in teractors of a teacher and a student in which a user plays a double role of them, (Journal of Information Processing.

Y.M. Manssour, H.M. El Daly, N. K. Morsi, The Historical Evolution of Museum

Z. Michael, Digital Art History and Concept, diakses tanggal 12 Januari 2019 dari https://www.theartstory.org, 